\title{
Vicki Cassman, una amiga extraordinaria
}

\author{
Liliana Ulloa ${ }^{1}$
}

En 1983 Vicki vino por primera vez a Chile como estudiante en práctica en el marco de un Acuerdo entre las universidades de Tarapacá y Delaware (USA) donde ella cursaba su Magister en Conservación de Arte. Su impresión fue grande al llegar a Arica y encontrarse con una gran cantidad de textiles arqueológicos en el Museo San Miguel de Azapa. Ella me confesó que, al enfrentarse a ellos, tuvo que cambiar completamente las estrategias de tratamiento aprendidas, ya que debido a la magnitud y características de la colección estos no podían ser tratados individualmente solo como "objetos de arte".

Vicki era una mujer luminosa, transparente, de una bondad infinita, muy inteligente y por supuesto se ganó rápidamente el cariño de todos en el Museo. Posteriormente se organizó un Convenio entre ambas Universidades, financiado por la Comisión Fulbrigth y en este contexto, ella volvió varias a veces a Arica como profesora, a cargo de otros estudiantes del mismo Magister.

Tuvo siempre un rol muy activo en relación a la conservación de las colecciones del Museo y fue así como desarrolló y propuso estrategias de manejo de colecciones, las que fueron conversadas, discutidas y consensuadas con todo el equipo del Museo, y algunas de las cuales están todavía vigentes. Su mirada profesional y certeras opiniones reforzaron aún más nuestras políticas de Conservación Preventiva a las que estábamos abocados. Las colecciones arqueológicas se observaron globalmente considerando diversos ámbitos relacionados con el traslado, embalaje, sistemas de depósito, catalogación, etc.

Posteriormente, e inspirada por las culturas prehispánicas del norte de Chile, obtuvo su doctorado en Arqueología, en la Arizona State Universtity (ASU).

Durante mi estadía en Winterthur, Delaware, como estudiante becada Fulbrigth disfruté con ella un tiempo valioso tanto en lo profesional porque fue mi profesora en una asignatura, como en lo personal y cotidiano porque fuimos amigas.

Fue para mí un honor haberla conocido y haber compartido tantas experiencias. Un ejemplo de mujer, generosa en la entrega de sus conocimientos y de su amistad.

Vicki, estarás siempre en nuestros recuerdos y ten la certeza que todo lo que sembraste durante tu vida seguirá dando frutos. Descansa en paz en ese lindo lugar donde elegiste estar para siempre.

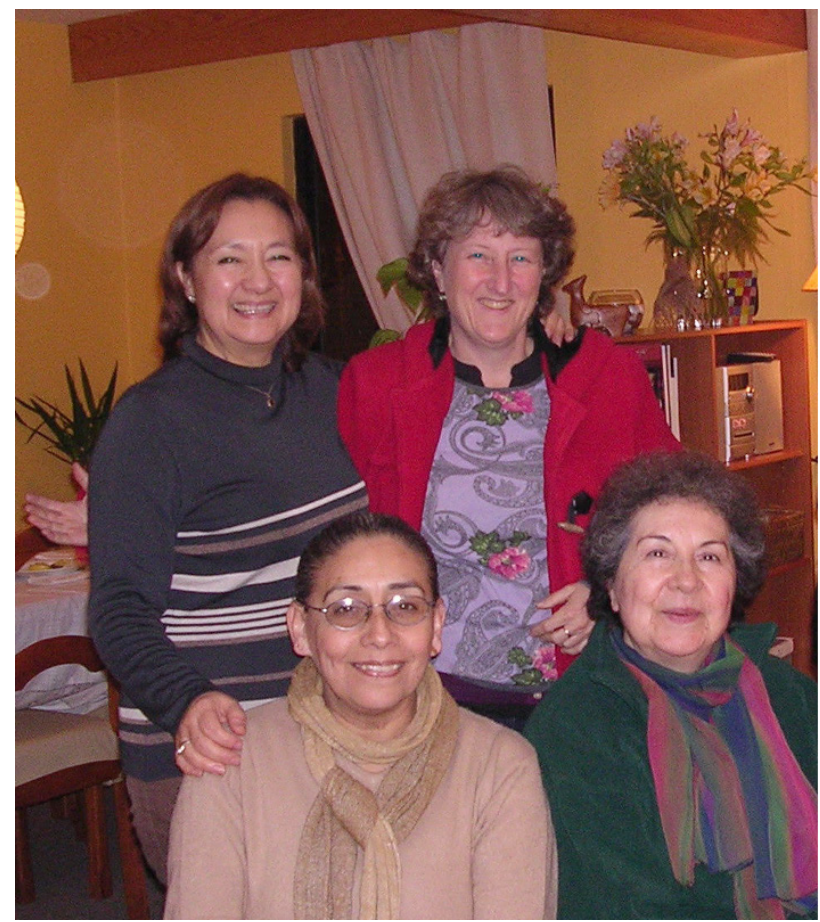

Liliana Ulloa y Vicki Cassman (de pie); Mariela Santos y Julia Córdova (sentadas). Arica, 2007. 